\title{
Remarks: The Simple Virtues of The Cathedral
}

\author{
Guido Calabresi ${ }^{\dagger}$
}

There is something odd about taking part in a discussion of one's own work. My mother-in-law was an artist and she hated to go to exhibitions of her paintings. She felt naked as people looked at her works and discussed them almost as if she weren't there. It is much the same when one listens to one's writings being analyzed. "Did I say that? Did I really say that? Of course I didn't say that!" Or conversely, "Of course I said that! Who could possibly think that I didn't? Obviously that idea was there. Anyone could tell it was there!" But who is to say whether it really was there in a meaningful sense?

As a teacher of products liability, I guess I'm committed to the notion that once one creates a product, an artifact, that artifact must speak for itself, it must be taken with all that its users find in it, or find to be missing from it. And one can't completely exonerate oneself from the damage done by a plausible use of the product by saying, "I didn't mean for it to be used that way." Still, one is tempted to suggest how one's artifact should and should not be used, and so here I am.

I'm very glad to see that Doug Melamed is also here; I wanted him to spring unexpected out of a cake-unfortunately there is no cake. But he is here, and you have had a chance to listen to him. I especially wanted him here because over the years many people have asked me, "Who was Melamed?" as if he didn't exist, as if he weren't one of the country's leading lawyers. Most of you, like me, are teachers and scholars, and we sometimes think of the world as one in which only scholarly achievements matter. We are, of course, quite wrong.

There was a man named Nathan Young, who graduated from the Yale Law School in 1918. He founded the NAACP in Missouri, and later became the first African-American judge in Missouri. On the seventieth anniversary of his graduation, he came back to the law school and spoke at commencement. To place him among his classmates, I got a list of the people who had graduated with him in 1918. Among them was Karl Llewellyn. Naturally, I asked Young if he knew Llewellyn and he said, "Karl Llewellyn . . . of course I knew Karl, we wrote a paper together-bright fellow ... What ever became of him?" So

$\doteqdot$ Judge, United States Coun of Appeals for the Second Circuit; Stering Professor Ementus of Law and Professorial Lecturer in Law, Yale Law School. 
if any of you don't know who Doug is, and what he has done, remember, it's a narrow world we live in.

I'd like to begin talking about The Cathedral with a bit of legal thought. Or rather, with some history of legal thought, if I may so dignify what I will say. First, a matter of timing: This article was written in the spring of 1971. It was written at about the same time that Dick Posner's review of The Costs of Accidents came out. In that review, Posner stated that he was not a torts lawyer, but then neither was Calabresi, because anyone who was doing something so startling as to use economic analysis of law to discuss accidents was not really talking about torts. ${ }^{1}$ In 1971, Mitch Polinsky was just starting as a graduate student at MIT. Nick Tideman, who, along with Saul Levmore, has done the most interesting work on self-assessment, had barely finished his $\mathrm{Ph} . \mathrm{D}$. at Harvard. Jules Coleman was not that long past puberty, and Jody Kraus was probably still in knee-pants. At that time, most people believed that economic analysis of law was crazy stuff.

Perhaps for that reason this article was almost rejected. It had been commissioned by the Harvard Law Review because I was a visiting professor at Harvard that year. When the editors looked at it, though, they were so startled by my way of approaching things that they nearly turned it down. (They ultimately published it with fewer changes than were made by editors in any other article I have written, but only after I was able to explain to them face-to-face what the piece was about.)

This context explains the simplicity, what Saul has kindly called "the elegance," of the model. ${ }^{2}$ The lack of any nuances, of any sub-rules and subsub-rules stems from the fact that, as simple as the model was, it was nonetheless almost too complex for its time. Susan Rose-Ackerman, in her classic article, has, for instance, sorted out many different types of inalienability: when one can give, but cannot sell; when one can sell, but cannot destroy; and so forth. ${ }^{3}$ All these (and other) crucial distinctions were omitted from The Cathedral not because I had the sense to make the model simple and elegant. They were left out because I had to make it simple so that people would understand it.

Ironically, the model's lack of complexity has been one of the reasons why The Cathedral has had so much influence. The simplicity of the article made it little more than an outline-a way of looking at things. As such, it leaves room for others. They can complicate the structure. They can use the model in areas different from those that spawned it. They can criticize it for its

1. See Richard A. Posner, The Costs of Accidents-A Legal and Economic Analysis, 37 U. CHI. L. REv. 636, 636 (1970).

2. See Saul Levmore, Unifying Remedies: Property Rules, Liability Rules, and Startling Rules, 106 YALE L.J. 2149, 2155 (1997).

3. See Susan Rose-Ackerman, Inalienability and the Theory of Property Rights, 85 CoLum. L. REv. 931, 934-35 (1985). 
omissions and want of subtlety, while at the same time relying on it. Of such versatility is influence made.

Second, I would like to talk about what Carol Rose has felicitously called "the shadow example." What was it that drove me to write the article? The most scholarly, and hence the best, review of The Costs of Accidents came out early in 1971. It was Frank Michelman's A Non-Accidental Perspective on Calabresi's Costs. ${ }^{5}$ In it, Frank took my discussion of accidents and showed how one could use the same type of economic analysis in other contexts. He adapted it to nuisance because he was teaching property. It was not surprising that he should choose nuisance since that is the field that lies right at the confluence of torts and property. His important work gave inspiration to my article.

Gary Becker was also a source, not in the sense of being an inspiration, but rather because I found one of his articles to be quite disturbing. ${ }^{\circ}$ In that article, Becker described criminal law as a simple pricing mechanism in which the penalty for a crime should be the value of a stolen good multiplied by the chances of not getting caught. And that seemed silly to me. I found it odd that Becker-who I thought would be appalled if, in the property context, anyone were allowed to demand your watch or your land in exchange for what some state agency said it was worth-seemed to say just that in a criminal setting. I said, "Becker can't mean it. Something is wrong with his analysis." Looking for what was wrong led me to the distinction between property and liability rules. Of course, looking for what was wrong also meant thinking about torts, contracts, and criminal law not as separate fields, but, rather, as all part of one system. And that, as Richard Epstein has so perceptively noted, is highly subversive. $^{\text {? }}$

Eminent domain is the model for both Rules 3 and 4. Of course, the situations in which we allow people to take some other person's goods freely after paying a collectively set price for the goods (a kind of private eminent domain) are very different from the situations in which people are only given the right to engage in activities that entail the distinct possibility (or almost certainty) that harm will befall others as a consequence. And they are different even though in the latter all that the actors need to do, once harm has occurred, is also to pay a collectively set price by way of compensation. But still, such situations-like driving a car or building a bridge, for example-are even more different from those that we regulate by contract. And this is so regardless of whether one views contracts as Epstein does, or if one accepts the so-called

4. Carol M. Rose, The Shadow of The Cathedral. 106 Y ALE LJ 2175, 2176 (1997)

5. Frank I. Michelman, Pollution as Tort: A Non-Accidental Perspectrie on Calabresi's Costs, 80 YALE L.J. 647 (1971).

6. See Gary S. Becker, Crime and Punislment: An Economic Approach, 76 J. POL. EcoN. 169 (1968).

7. See Richard A. Epstein, A Clear View of The Cathedral: The Dominance of Properny Rules, 106 YALE L.J. 2091, 2103-05 (1997). 
Holmesian heresy that people have a right to breach a contract and pay damages. $^{8}$

In the end though, The Cathedral did not intend to take sides on whether Holmes or Epstein is right, or even on whether we should price crimes in the way Becker seemed to suggest. It was intended to provide a framework, a little simple-minded model, that would give rise to boxes and thereby encourage scholars to see whether there might be situations in the world that filled those boxes. It was designed to help us shed light on things that the common law method left in the dark. One of these was the 4th Rule. There were virtually no cases at common law exemplifying this Rule. As a result, legal scholars, who looked only at cases, did not realize its existence. And this was so even though outside of appellate cases-in the administrative world, in eminent domain, and in all sorts of other areas-the 4th Rule, as Melamed has said, is alive and well. ${ }^{9}$

In addition, the article was a way of saying that we can look at a situation and consider whether one rule is more appropriate than another in terms that go beyond efficiency and allow decisionmakers to respond, for example, to distributional desires as well. It is for this reason that I have relatively little patience with the debate over which is more efficient, a property rule or a liability rule when transaction costs are high or low. This debate is certainly worth having, but it is not as interesting as the question of when we want to use one remedy rather than another for broader reasons.

I have one more point about intellectual history, and that concerns young James Atwood. Most of you don't know about Atwood. But when you read all of these Essays, you will learn that he was a student, who, in a law review Note in 1969 , pointed out the existence of a 4 th rule. ${ }^{10}$ I wish he too were here-I'd like to meet him. I am very glad he was found. The Atwoods of this world should be recognized; they are always there! As Itzak Englard pointed out in writing about my article, Concerning Cause and the Law of Torts, and its definition of causal link or causal tendency," some people had said the same thing in German in the nineteenth century. ${ }^{12}$ Even if they are ignored at the time, such people should always be given credit later when the idea they

8. See Oltver Wendell Holmes, The Common laW 301 (1881) ("The only universal conscquence of a legally binding promise is, that the law makes the promisor pay damages if the promised event does not come to pass."). Epstein argues that the remedies for breach encompass not only damages, but also in the appropriate case, specific performance. See Richard A. Epstein, Toward a Revitalization of the Contract Clause, 51 U. CHI. L. REV. 703, 741 (1984).

9. See A. Douglas Melamed, Remarks: A Public Law Perspective, 106 YALE L.J. 2209, 2209 (1997).

10. See James R. Atwood, Note, An Economic Analysis of Land Use Conficts, 21 STAN. L. RBV. 293, 315 (1969).

11. See Guido Calabresi, Concerning Cause and the Law of Torts, 43 U. CHI. L. REV. 69 (1975).

12. See Izhak Englard, Victor Mataja's Liability for Damages from an Economic Viewpoint: $A$ Centennial to an Ignored Economic Analysis of Tort, 10 INT'L REV. L. \& ECON. 173, 179 (1990) (describing Austrian scholar's 1888 book, which was published in German and largely ignored in American scholarship). 
expressed, perhaps too soon, becomes popular as a result of someone else's writings. For this reason, the fact that Atwood has now been found delights me. ${ }^{13}$

I would now like to share a few thoughts on substance. Of course, the socalled remedy defines the nature of the right, as Jules Coleman and Jody Kraus, ${ }^{14}$ and Carol Rose have said. ${ }^{15}$ Indeed, I (probably incorrectly) thought I had said as much in the article itself. The nature of the entitlement depends on the circumstances; property rules and liability rules do not attach to things-not to cars, watches, lands, or bodies-they only attach to things in particular circumstances, in a particular context. When does society or its legal system give you a right to take my entitlement? When does society give you a right to act in ways that may cause such a taking to occur? When does it do it by saying you can pay $X$ amount, or by making you pay $Y$, or $Y$ plus $Z$ ?

For that matter, when does society say you must pay $Y$ plus $Z$, but you must also suffer stigma, because society doesn't really want you to take my entitlement? When does society say not only must you pay but we will also kick you out of the trade association, or use the rack, the whip, or the thumbscrew on you if you take my entitlement unilaterally? These are the questions that are ultimately worth asking. And that is why I find the abstract discussion of when property rules are better than liability rules not all that helpful. I find the discussion instead very helpful when it takes place in a context, when it asks in a given situation why one rule is better than another.

And of course, the cost of costing is important. So when Krier and Schwab say that we must always take into account how much it costs to define the amount of compensation to be given, they are right. ${ }^{16}$ But we must equally take into account what it costs people to define the price at which they would sell, if we were to use property rules instead. Most of the time we think this latter cost is not much. Yet the moment one thinks of all the attempts-whether they are through sequential auctions ${ }^{17}$ or selfassessments ${ }^{18}$-at determining the price at which a person will sell, one

13. After the AALS session, Doug Melamed told me something that sheds yet more light on how ideas proliferate. Atwood and Melamed had been students in the same seminar taught al Yale College by $\mathrm{C}$. Edward Lindblom, a great and innovative scholar whose work-betwoen political science and economics-was troublesome to both fields. I too studied with Lindblom, though considerably earher. I do not think for a moment that Lindblom "taught" us Rule 4, and neither does Melamed. But is it too farfetched to think that Lindblom's characteristic and unusual approach encouraged three of his students to look at things in a way that would lead to the same insight?

14. See Jules L. Coleman \& Jody Kraus, Rethinking the Theory of Legal Rights. 95 YALE LJ 1335. $1342-43$ (1986).

15. See Rose, supra note 4 , at 2179.

16. See James E. Krier \& Stewart J. Schwab, Property Rules and Liability Rules: The Cathedral in Another Light, 70 N.Y.U. L. REv. 440, 454-55 (1995).

17. See Ian Ayres \& J.M. Ballin, Legal Entitlements as Auchons: Property Rules, Labulin Rules, and Beyond, 106 YALE L.J. 703 (1996). (1982)

18. See Saul Levmore, Self-Assessed Valuation Systems for Tort and Other Law. 68 VA. L REV. 771 
realizes how high the latter cost can also be. Then we are back to Coase's insight-there is no free lunch. Everything has costs: There is a cost to liability ways of shifting entitlements, and there is also a cost to any other way of doing it. Inevitably these relative costs are important factors to consider in deciding which approach to use in any particular situation. It will influence when we will let people get entitlements by paying a collectively set price and when, instead, we will require them to pay a negotiated price. It will also influence whether, if they don't pay a negotiated price, we will assess "extra" or punitive damages, throw them in jail, or simply throw them out of the country club.

I'd like to close by mentioning two current special interests that I have in this area. The first is "splitting." I think the major change in tort law in the last thirty years (a change as important as the coming of insurance was seventy years ago) is the fact that we no longer are governed solely by "all-or-nothing" rules. ${ }^{19}$ Dramatically, since the coming of comparative negligence, we split damages all the time and in all sorts of ways. We are splitting between faulty and non-faulty behavior that combine to cause injury, for example. Someday we may even be splitting proximate cause, saying, yes, there is a proximate cause, but it is only somewhat proximate, so the plaintiff should get part, but not all, of the damages suffered. The whole nineteenth-century notion that recovery is an all-or-nothing thing is disappearing. Moreover, the increasing use of liability rules is another example of this very phenomenon because liability rules produce splits. As Carol Rose has pointed out, they allow for forms of splitting that are remarkably complicated ${ }^{20}$ As a result, I'd like to see more work done with The Cathedral rules as techniques for splitting.

The other thing that I'm interested in these days is bodies: whether we own our own bodies and body parts, and who owns them, who has a right to them, if we don't. That's the context in which l'd like to ask whether and when we have rights protected by property rules, semi-property rules, sub-rules of the sort Rose-Ackerman wrote about, ${ }^{21}$ or reverse rules. Can I claim that you are injuring me if you don't give me the body part that I need for a transplant? Does the possessor of the functioning body part then have the right to invoke the Krier-Schwab rule, saying, "Okay, I'll give it to you, but you must pay me the damages you sought from me when you were trying to induce me to give it to you?" I especially like the idea of looking at these rules in the impossible context of body parts, where most of us say (even more than in property) that what is mine is mine, but where it turns out (just as it did in the

19. See Guido Calabresi \& Jeffrey O. Cooper, New Directions in Tort Law, 30 ValParalso U. L. REV. 859, 868-83 (1996).

20. See Rose, supra note 4 , at $2182-87$.

21. See Rose-Ackerman, supra note 3, at 949-51. 
context of property) that sometimes that is not so. Once again, I am inclined to conclude that the article's simple framework may be useful in surprising ways in analyzing body parts. If so, the next twenty-five years of The Cathedral are assured. 
HeinOnline -- 106 Yale L.J. 2208 1996-1997 